\title{
Toward a translational approach to targeting the endocannabinoid system in posttraumatic stress disorder: A critical review of preclinical research
}

\author{
Santiago Papini ${ }^{a, b}$, Gregory M. Sullivan ${ }^{a, c}$, Denise A. Hien ${ }^{a, b, c}$, Erel Shvil ${ }^{a, c}$, and Yuval \\ Neria ${ }^{a, c,{ }^{*}}$ \\ aNew York State Psychiatric Institute, 1051 Riverside Drive, New York, NY, 10032, USA \\ ${ }^{b}$ City College of New York, 160 Convent Avenue, New York, NY, 10031, USA \\ ${ }^{c}$ Columbia University Medical Center, W. 168th Street, New York, NY, 10032, USA
}

\section{Abstract}

Despite the lack of clinical research, marijuana and synthetic cannabinoids have been approved to treat posttraumatic stress disorder (PTSD) in several states in the United States. This review critically examines preclinical research on the endocannabinoid system (ECS) in order to evaluate three key questions that are relevant to PTSD: (1) Does ECS dysfunction impact fear extinction? (2) Can stress-related symptoms be prevented by ECS modulation? (3) Is the ECS a potential target for enhancing PTSD treatment? Disruption of the ECS impaired fear extinction in rodents, and ECS abnormalities have been observed in PTSD. Targeting fear memories via the ECS had mixed results in rodents, whereas augmented cannabinoid receptor activation typically facilitated extinction. However, the translational value of these findings is limited by the paucity and inconsistency of human research. Further investigation is necessary to determine whether incorporating cannabinoids in treatment would benefit individuals with PTSD, with cautious attention to risks.

\section{Keywords}

Endocannabinoid; Cannabinoids; Marijuana; PTSD; Fear extinction; Reconsolidation; Trauma

\section{Introduction}

Beginning with California in 1996, twenty-three states in the United States have legalized marijuana for medicinal purposes. Seven of these states have listed posttraumatic stress disorder (PTSD) as an approved condition for treatment with the drug (National Council of

\footnotetext{
(C) 2014 Published by Elsevier B.V.

"Corresponding author at: New York State Psychiatric Institute, Unit: 69, 1051 Riverside Drive, New York, NY 10032, USA. Tel.: +1 646774 8092.ny126@columbia.edu (Y. Neria).

Disclosure statement

G. M. Sullivan has served as a consultant for Ono Pharma USA Inc. and as a consultant and scientific advisory board member for Tonix Pharmaceuticals Inc.; Y. Neria receives funding from Grand Challenges Canada, and Cambridge University Press. S. Papini, D.

A. Hien, and E. Shvil report no competing interests.
} 
State Legislatures, http://www.ncsl.org/research/health/state-medical-marijuana-laws.aspx), but unlike other medical conditions for which cannabis is prescribed, there have been no clinical trials testing the efficacy of treating PTSD with cannabis. Moreover, recreational use of cannabis has been associated with a range of poor psychosocial outcomes (Hall, 2014) as well as symptoms of mood, anxiety, and psychotic disorders (Crippa et al., 2009; Moore et al., 2007), suggesting complex effects that require careful assessment of risk alongside any examination of potential benefits. Symptoms of PTSD, including exaggerated reactivity to trauma-related reminders, anxiety, hyperarousal, and avoidant behaviors (American Psychiatric Association, 2013) can undermine functioning for years (Neria et al., 2013), therefore developing novel treatments is crucial, and drawing from research on the behavioral and neurobiological components of PTSD is the best approach for evaluating the therapeutic potential of cannabis.

Several laboratory models have expanded the understanding of PTSD-like symptoms across key levels of analysis (Sullivan, Debiec, Bush, Lyons, \& Ledoux, 2009), providing important tools for the rigorous experimentation of potential treatments. Classical fear conditioning (Pavlov, 1927) has been examined at the genetic (Hettema, Annas, Neale, Kendler, \& Fredrikson, 2003; Jovanovic \& Ressler, 2010), synaptic (Amano, Unal, \& Paré, 2010; Myers \& Davis, 2007), neurocircuitry (Rauch, Shin, \& Phelps, 2006; Shin \& Liberzon, 2010), and behavioral (Delamater, 2004) levels, and extensively studied in the context of anxiety in humans (Bitterman \& Holtzman, 1952; Lissek et al., 2005; Milad \& Quirk, 2012). Inhibitory avoidance and fear-potentiated startle paradigms also model behavioral and physiological disturbances relevant to PTSD (Grillon, 2002; Grillon \& Morgan III, 1999). In all these models, extinction is the learning process during which a conditioned response attenuates after repeated exposure to the conditioned stimulus in the absence of the aversive, unconditioned stimulus (Delamater, 2004; Myers \& Davis, 2002).

Several findings point to the applicability of these models in the study of PTSD.

Heterogeneous patterns of fear extinction learning have been observed in rats, with rates of rapid, slow, and failed extinction that mirror human trajectories of PTSD symptoms after trauma (Galatzer-Levy, Bonanno, Bush, \& LeDoux, 2013). More than with any other psychiatric condition, research has linked PTSD to dysfunctional fear extinction in laboratory paradigms, coupled with impairments in brain regions that are part of the fear circuitry (Fani et al., 2012; Garfinkel et al., 2014; Inslicht et al., 2013; Milad, Orr, Lasko, Chang, Rauch, \& Pitman, 2008; Milad et al., 2009; Norrholm, Jovanovic, Olin, Sands, Bradley, \& Ressler, 2011; Orr, Milad, Metzger, Lasko, Gilbertson, \& Pitman, 2006; Rougemont-Bücking et al., 2011; Shvil et al., 2014; Sripada, Garfinkel, \& Liberzon, 2013). Extinction deficits may be premorbid risk factors for the development of PTSD (Guthrie \& Bryant, 2006). Moreover, impaired ability to extinguish fearful associations to traumarelated cues may interfere with treatment response.

In fact, the core mechanism of prolonged exposure therapy (Foa, Hembree, \& Rothbaum, 2007), a first-line PTSD treatment (Powers, Halpern, Ferenschak, Gillihan, \& Foa, 2010), is extinction learning through behavioral and cognitive techniques (Bouton, Mineka, \& Barlow, 2001; Hofmann, 2008; Rothbaum \& Davis, 2003). Patients recount their trauma multiple times within sessions (i.e., imaginal exposure) and complete assignments during 
which avoided situations are repeatedly confronted in a gradual manner (i.e., in vivo exposure). However, some patients who benefit from this empirically-validated treatment experience the relapse of symptoms (Vervliet, Craske, \& Hermans, 2013), which is consistent with the phenomenon of spontaneous recovery of conditioned fear in experimental models relevant to PTSD (Bouton, García-Gutiérrez, Zilski, \& Moody, 2006; Rescorla, 2004). This has led to the consideration of adjunctive pharmacologic approaches for enhancing extinction learning retention during exposure therapy (Kaplan \& Moore, 2011).

A potential pharmacological target for enhancing extinction learning and retention is the endogenous cannabinoid system (ECS), which includes cannabinoid receptors, endocannabinoid neurotransmitters such as anandamide, and enzymes responsible for the breakdown and reuptake of endocannabinoids (Di Marzo, Bifulco, \& De Petrocellis, 2004). High densities of endocannabinoid receptors are present in the hippocampus, amygdala, and prefrontal cortex (Glass, Dragunow, \& Faull, 1997)—brain regions with key roles in fear acquisition and extinction (Quirk \& Mueller, 2008) that have exhibited structural and functional impairments in patients with PTSD (Admon, Milad, \& Hendler, 2013; Garfinkel $\&$ Liberzon, 2009). Approaches to understanding the role of the ECS on the acquisition, consolidation, and extinction of fear responses have included the use of transgenic mice lacking cannabinoid type 1 (CB1) receptors, and pharmacological methods including administration of exogenous CB1 antagonists and agonists, and inhibitors of enzymes involved in the breakdown and reuptake of endocannabinoids.

Several reviews have examined the role of the ECS in fear-related processes, highlighting the neurobiological mechanisms derived from animal research (Akirav, 2011; GunduzCinar, Hill, McEwen, \& Holmes, 2013; Lutz, 2007; Ruehle, Rey, Remmers, \& Lutz, 2012), offering concise summaries of cannabinoid research within general expositions of several potential extinction enhancers (de Bitencourt, Pamplona, \& Takahashi, 2013; Fitzgerald, Seemann, \& Maren, 2014), or examining broad therapeutic potential across mood and anxiety disorders (Hill \& Patel, 2013; Micale, Di Marzo, Sulcova, Wotjak, \& Drago, 2013; Neumeister, 2013; Rabinak \& Phan, 2014) or schizophrenia (Kucerova, Tabiova, Drago, \& Micale, 2014). The present review is focused on the potential role of the ECS in several distinct processes (i.e., fear expression, memory consolidation and reconsolidation, fear extinction, and extinction retention) each with potential implications for risk, early intervention, and treatment of PTSD.

Although the ECS may play a role in processes relevant to several psychiatric disorders, this review focuses on PTSD for several reasons. First, the inclusion of PTSD as one of the approved conditions for treatment with cannabis in several regions of the United States is unique among psychiatric diagnoses, necessitating a careful review of the available scientific evidence. Second, the PTSD diagnosis is unique in DSM nosology in that an etiological stressor (i.e., traumatic event) is one of the diagnostic requirements. The relative unpredictability of human trauma exposure is one of the greatest challenges of experimental research on PTSD, making the use of laboratory paradigms that model stressful events in a controlled environment particularly useful for elucidating pathophysiological mechanisms of 
PTSD-like symptoms, which include exaggerated reactivity to innocuous cues, avoidance behavior, emotional numbing, and hyperarousal of physiological states.

No laboratory model can fully capture the complex human response to traumatic experiences; however, work with animals and humans has linked several experimental paradigms to PTSD-a necessary step in the evaluation of the translatability of ECS manipulations of these paradigms. Toward this aim, data from animal models and preclinical studies with humans are synthesized in a critical examination of results with cautious attention to inconsistencies, potential risks, and translational value of findings to clinical application. The reviewed research is organized into three sections covering: (1) evidence of the impact of ECS dysfunction on fear-related processes; (2) the feasibility of decreasing the risk of PTSD-like symptoms by modulating endocannabinoid neuro-transmission shortly after stress exposure and; (3) the potential to augment existing treatments with a pharmacologic adjunct targeting the ECS.

\section{Methods and materials}

A systematic search of the peer-reviewed literature was conducted on PsycINFO, PubMed, and Google Scholar utilizing the key words 'endocannabinoid', 'cannabinoid', 'cannabis', 'marijuana', and 'CB1' in combination with 'fear conditioning', 'fear extinction', 'memory consolidation', 'reconsolidation', 'PTSD', 'inhibitory avoidance', 'fear-potentiated startle', and 'stress'. Articles from 2002 (year of first experiment in this area) to 2014 were selected that involved manipulation of the ECS in experimental models chosen on the basis of their relevance to PTSD symptoms (Siegmund \& Wotjak, 2006; Yehuda \& Antelman, 1993). In delay (cue) conditioning paradigms, a neutral, conditioned stimulus (CS+; e.g., a tone) is followed by an aversive, unconditioned stimulus (US; e.g., shock) such that subsequent exposure to the CS+ alone elicits a fear response (e.g., freezing). In contextual conditioning, the context itself (e.g., conditioning box in which a shock was delivered) evokes the fear response upon subsequent exposure. Similar brain structures in animals and humans are involved - both delay and contextual fear conditioning rely on the amygdala (LeDoux, 2001), but only contextual fear responses rely on the hippocampus (Marschner, Kalisch, Vervliet, Vansteenwegen, \& Buchel, 2008; Phillips \& LeDoux, 1992). In inhibitory avoidance paradigms, animals avoid an area of the conditioning box (e.g., dark side) where they have previously received a painful shock. Extinction of this avoidance behavior is hippocampal dependent (Quirk \& Gehlert, 2003; Vianna, Coitinho, \& Izquierdo, 2004). In fear-potentiated startle paradigms, startle probes (e.g., noise bursts) are presented alone or in conjunction with a CS+ previously paired with an aversive US. Exaggerated startle on trials that pair probes with the CS+ suggests hyperpotentiation of this basic reflex by fear conditioning (Davis, 2006); extinction of this response is amygdala dependent (Falls, Miserendino, \& Davis, 1992; Lu, Walker, \& Davis, 2001).

\section{Results}

\subsection{Does ECS dysfunction impact fear extinction?}

3.1.1. Animal research-There is strong evidence that disruption of the ECS impairs extinction (Table 1). Genetically altered mice lacking CB1 receptors (i.e., CB1 knockout 
mice) have consistently demonstrated normal acquisition of conditioned freezing behavior to cues, but a significant impairment in both within-session extinction learning, and subsequent extinction retention, suggesting a critical role of CB1 receptors specific to the extinction of fear (Cannich, Wotjak, Kamprath, Hermann, Lutz, \& Marsicano, 2004; Dubreucq et al., 2012; Kamprath et al., 2006; Marsicano et al., 2002). These deficiencies were exhibited by animals that began extinction training one (Cannich et al., 2004; Dubreucq et al., 2012; Kamprath et al., 2006; Marsicano et al., 2002), three (Dubreucq et al., 2012), or six (Cannich et al., 2004; Kamprath et al., 2006; Marsicano et al., 2002) days after fear acquisition. Moreover, impairments in extinction memory retention were sustained as far as 11 days after acquisition, suggesting a long-term effect of CB1 receptor ablation during extinction (Marsicano et al., 2002). However, when subjected to several extinction sessions CB1 knockout mice only exhibited deficient within- but not between-session extinction (Plendl \& Wotjak, 2010).

Additional testing indicated that the effects on extinction were not due to sensory-motor dysfunction in the CB1-knockout mice, as they displayed no differences in sensitivity to shock intensity, unconditioned freezing, sensitization to the tone, locomotion in an open field test, or anxiety-related behavior on the elevated plus maze (Marsicano et al., 2002). However, in two experiments employing extended CS presentations during extinction (consistent with the method of prolonged exposure therapy for PTSD), both extinction after fear conditioning to a tone paired with shock, and habituation to tone-only presentations after sensitization with shock, were impaired in the CB1 knockout mice, suggesting a role for the ECS that may extend beyond associative learning processes (Kamprath et al., 2006). Impaired fear adaptation after single inescapable footshock was also observed in mice with CB1 receptors knocked out in principle forebrain or cortical glutamatergic neurons (Kamprath et al., 2009).

In a contextual fear conditioning paradigm, CB1 knockout mice only exhibited deficient extinction of freezing when they were conditioned with a higher intensity (1.5 vs. $0.70 \mathrm{~mA}$ ) footshock (Jacob, Marsch, Marsicano, Lutz, \& Wotjak, 2012). However, in an experiment that also applied the lower $0.70 \mathrm{~mA}$ footshock, mice whose CB1 receptors were conditionally knocked out in dopamine-1 receptor expressing neurons exhibited higher levels of both auditory and contextually conditioned fear, as well as poorer within-session extinction (Terzian, Drago, Wotjak, \& Micale, 2011). This suggests the impact of CB1 ablation varies by site.

An important limitation of research with CB1 knockout mice is that the consequences of absent CB1 signaling during acquisition and extinction cannot be separated from the developmental impact of life-long CB1 system deficiency on these processes. Moreover, manipulation of CB1 signaling cannot be isolated to a specific stage in the procedure, or localized to brain regions. Accordingly, CB1 receptor antagonists have been utilized to examine the impact of acute pharmacological blockade of CB1 receptors during different stages of fear conditioning paradigms. In one case, contextual fear memory was enhanced (i.e., increased freezing 1 day after conditioning) when mice were treated with a CB1 antagonist during acquisition (Lin et al., 2011); however, extinction was not assessed. Studies employing mice and several rat strains have consistently demonstrated impairments 
in extinction of conditioned responses to cues (Bowers \& Ressler, 2014; Dubreucq et al., 2012; Kamprath et al., 2006; Marsicano et al., 2002; Plendl \& Wotjak, 2010) and contexts (Pamplona, Prediger, Pandolfo, \& Takahashi, 2006; Pamplona, Bitencourt, \& Takahashi, 2008; Reich, Mohammadi, \& Alger, 2008; Suzuki, Josselyn, Frankland, Masushige, Silva, \& Kida, 2004), of inhibitory avoidance (Niyuhire, Varvel, Thorpe, Stokes, Wiley, \& Lichtman, 2007), and of fear-potentiated startle (Chhatwal, Davis, Maguschak, \& Ressler, 2005; Chhatwal et al., 2009) when CB1 antagonists were administered systemically prior to extinction learning. In some cases, these impairments were dose-dependent (Chhatwal et al., 2005; Suzuki et al., 2004) and often sustained in drug-free extinction retention tests (Chhatwal et al., 2005; Marsicano et al., 2002; Suzuki et al., 2004). However, these deficits were not present in animals that received treatment prior to fear acquisition but not during extinction (Marsicano et al., 2002; Reich et al., 2008; Suzuki et al., 2004), suggesting that only blockade of CB1 receptors specifically during extinction training impaired extinction learning and its retention.

Although the majority of experiments administered the CB1 receptor antagonist treatment intraperitoneally (i.e., systemic), specific brain regions that are part of the fear circuitry have also been directly targeted. Pre-extinction intracerebral infusion of CB1 antagonist into the CA1 hippocampal subregion (Abush \& Akirav, 2010; de Oliveira Alvares, Genro, Diehl, Molina, \& Quillfeldt, 2008a), and the infralimbic — homologous to the human vmPFC, (Lin, Mao, Su, \& Gean, 2009) or medial prefrontal cortex (mPFC; Kuhnert, Meyer, \& Koch, 2013) had impairing effects on extinction of conditioned freezing, fear-potentiated startle, and inhibitory avoidance. However, pre-extinction CB1 antagonist infusion in the basolateral amygdala (BLA) had inconsistent effects, impairing extinction of inhibitory avoidance (Ganon-Elazar \& Akirav, 2009) but not of fear-potentiated startle (Kuhnert et al., 2013), highlighting a potential divergence in how the amygdala modulates these two types of responses. Together, this body of rodent research employing a variety of paradigms and measures of fearful responding, provide strong evidence of the ECS's central role in fear extinction. Dysfunction of the ECS - whether by genetic or pharmacological manipulation - consistently disrupted extinction learning and retention in translational animal models relevant to PTSD symptoms that involve conditioned reactivity, avoidance behavior, and exaggerated startle.

3.1.2. Human research-To date, the effect of $\mathrm{CB} 1$ receptor blockade on extinction learning in humans has not been directly examined. However, meta-analyses of clinical trials of the CB1 antagonist rimonabant for the treatment of obesity found an increased risk of adverse psychiatric outcomes, including suicidal ideation (Christensen, Kristensen, Bartels, Bliddal, \& Astrup, 2007; Rucker, Padwal, Li, Curioni, \& Lau, 2007), which may indicate a pharmacologic effect of CB1 antagonism on mood. Moreover, healthy human carriers of a genetic polymorphism associated with reduced CB1 receptor expression exhibited impaired fear extinction in a virtual reality environment (Heitland, Klumpers, Oosting, Evers, Leon Kenemans, \& Baas, 2012).

Among individuals with PTSD, there is emerging evidence of dysfunctional endocannabinoid signaling. A positron-emission tomography study (Neumeister et al., 2013) found that individuals with PTSD had 20\% elevation in CB1 receptor availability, and over 
$50 \%$ reduction in peripheral concentration of the endocannabinoid neurotransmitter anandamide. The authors suggested that the upregulation of endocannabinoid receptors, which they found in the amygdala-hippocampal-cortico-striatal circuitry, was likely a secondary consequence of low anandamide levels. However, a small pilot study detected higher plasma concentrations of anandamide in PTSD patients that were positively correlated with the severity of their symptoms (Hauer et al., 2013). Although these results are contradictory, they provide evidence of dysregulated endocannabinoid signaling in humans with PTSD relative to healthy controls with or without trauma histories. Further research is needed in order to better characterize the dysfunction, and to determine whether it is a pre-existing trait or a sequela of PTSD development.

\subsection{Can stress-related symptoms be prevented by ECS modulation?}

3.2.1. Animal research-Memory consolidation is the neurobiological process through which new experiences are stored as stable long-term memories (McGaugh, 2000). Targeting memory consolidation has unique implications for PTSD; if exaggerated fearful memories can be attenuated shortly after trauma, it may help prevent the development of PTSD symptoms. In contextual and cued fear conditioning with rodents, memory consolidation can be disrupted by inhibition of protein synthesis (Schafe, Nadel, Sullivan, Harris, \& LeDoux, 1999). However, this method is not safe for humans, leading researchers to seek other consolidation blockers. In experiments targeting consolidation of fear memories (Table 2), animals were typically treated after acquisition training and subsequently tested for cued recall of fear memory (Fig. 1). Systemic, post-acquisition enhancement of endocannabinoid neurotransmission via inhibition of the catabolic enzyme fatty acid amide hydrolase (FAAH) had no effect on memory consolidation of conditioned freezing responses to cues (Gunduz-Cinar, MacPherson, et al. 2013) or of inhibitory avoidance (Mazzola et al., 2009). In several experiments, consolidation of contextual fear in rats was reduced by systemic CB1 agonist before (Lin et al., 2011) or after (Maćkowiak, Chocyk, Dudys, \& Wedzony, 2009) conditioning, but in other cases neither agonists nor antagonists had an effect (Pamplona et al., 2008; Reich et al., 2008). In the inhibitory avoidance paradigm, memory consolidation was blocked by THC administered immediately after training, but not $10 \mathrm{~min}$ after highlighting the time-dependent nature of effects on memory (Mishima et al., 2001). However, a subsequent study applying a similar technique found no effect of THC on memory consolidation even when it was administered immediately after training (Mazzola et al., 2009).

Targeting specific brain regions to block memory consolidation has also yielded inconsistent results (Table 2). Consolidation in hippocampal-dependent paradigms (i.e., inhibitory avoidance and contextual fear conditioning) was typically weakened via intra-CA1 FAAH inhibition prior to (Lin et al., 2011) or CB1 agonist treatment immediately after conditioning (Atsak et al., 2012; Jamali-Raeufy, Nasehi, \& Zarrindast, 2011; Moshfegh, Babaei, Oryan, Soltani, \& Zarrindast, 2011; Nasehi, Sahebgharani, Haeri-Rohani, \& Zarrindast, 2009; Piri \& Zarrindast, 2011) but opposite effects have also been observed with anandamide, which may be due to its binding to several receptors in addition to CB1 (de Oliveira Alvares, Genro, Diehl, \& Quillfeldt, 2008). Moreover, post-acquisition antagonist treatment in the CA1 also weakened consolidation of inhibitory avoidance (de Oliveira Alvares et al., 2005; 
de Oliveira Alvares, Genro, Diehl, \& Quillfeldt, 2008), suggesting that both over- and under-activation of hippocampal CB1 receptors can have an amnesic effect. Targeting the rat amygdala after stress exposure with a CB1 agonist blocked (Segev \& Akirav, 2011; Zarrindast, Babapoor-Farrokhran, Babapoor-Farrokhran, \& Rezayof, 2008) or dosedependently enhanced (Campolongo et al., 2009) memory consolidation depending on the specific subregion (i.e., basolateral or central) and paradigm (i.e., avoidance or contextual conditioning), whereas intra-BLA antagonism reduced fear consolidation across both paradigms (Bucherelli, Baldi, Mariottini, Passani, \& Blandina, 2006; Campolongo et al., 2009). In one experiment, memory consolidation of fear-potentiated startle was blocked with either direct agonist infusion in the BLA, but not mPFC, (Kuhnert et al., 2013) or with antagonist infusion in the mPFC, but not BLA (Kuhnert et al., 2013). These reciprocal effects in the BLA and mPFC highlight the complexity of memory consolidation processes and point to a challenge for human applications, where treatments targeting specific brain regions are not available.

When a memory is reactivated by a cue or context, it is subsequently restored through a time-limited, protein-synthesis dependent process termed reconsolidation (Nader \& Hardt, 2009; Nader, Schafe, \& Le Doux, 2000; Tronson \& Taylor, 2007). In contrast to extinction, which involves extended or repeated presentations of the $\mathrm{CS}+$, reconsolidation of a fear memory is prompted by reactivation through a single or brief presentation of the CS+. Extinction results in a new memory that competes with the conditioned fear memory whereas reactivation opens the window of reconsolidation during which the original memory enters a labile state, subject to modification (Lee, Milton, \& Everitt, 2006; Monfils, Cowansage, Klann, \& LeDoux, 2009; Pedreira \& Maldonado, 2003; Suzuki et al., 2004). Thus, targeting reconsolidation of distressing memories in the days or weeks after traumatic exposure may have potential as either an early intervention implemented prior to the development of symptoms, or as a treatment target once PTSD has been diagnosed.

Animal researchers have examined whether reconsolidation can be disrupted by manipulation of the ECS. The effect of CB1 antagonist administration after memory reactivation depended on the site: systemic administration had no effect on reconsolidation of contextual fear memory (Suzuki et al., 2004), infusion into the rat CA1 hippocampal subregion strengthened fear reconsolidation, resulting in greater recall of the fear response for up to 7 days (de Oliveira Alvares, Genro, Diehl, Molina, et al., 2008), and infusion into the rat BLA blocked reconsolidation for up to 8 days (Ratano, Everitt, \& Milton, 2014). Conversely, post-reactivation CB1 agonism in the BLA (Lin, Mao, \& Gean, 2006), infralimbic (Lin et al., 2009), or CA1 (de Oliveira Alvares, Genro, Diehl, Molina, et al., 2008) all blocked reconsolidation of fear responses. In contrast to the relative inefficacy of targeting fear consolidation, these results with rodents are more consistent in demonstrating that fear memory reconsolidation may be weakened with CB1 agonists. However, FAAH inhibition after reactivation enhanced only short term fear reconsolidation, with rats exhibiting increased freezing 1 but not 8 days after reactivation (Ratano et al., 2014). Moreover, situational reminders in the days after shock exposure exacerbated PTSD-like symptoms in rats, including impaired extinction of avoidance behavior and enhanced startle, 
but these effects were blocked in the group of rats that received CB1 agonist two hours after shock (Korem \& Akirav, 2014).

The need for preventive interventions is also underscored by research indicating that individuals who have recovered from the effects of a previous trauma exposure are at higher risk of developing PTSD if they experience additional traumatic events (Breslau, 2009). Similarly, animals exposed to stress subsequently exhibit enhanced conditionability (Cordero, Venero, Kruyt, \& Sandi, 2003) and impaired extinction of fear responses (Izquierdo, Wellman, \& Holmes, 2006). These two types of effects were blocked in rats by systemic (Ganon-Elazar \& Akirav, 2012), intra-BLA, or intra-hippocampal—but not intrainfralimbic_-(Ganon-Elazar \& Akirav, 2013) infusions of a CB1 agonist. Infusions were effective when administered immediately after the stressful event and up to 24 but not 48 hours later, suggesting a limited window of intervention. Similar results occurred when intra-BLA infusions of the CB1 agonist were administered prior to the prolonged stress (Ganon-Elazar \& Akirav, 2009), suggesting a possible avenue of preventive action when the occurrence of severe, stressful experiences can be predicted (e.g., combat, first responder activities). Pre-extinction inhibition of FAAH also reversed the impairing effect of adolescent trauma on extinction in adulthood in male rats (Moore, Gauchan, \& Genovese, 2014).

\subsection{Is the ECS a potential target for enhancing PTSD treatment?}

3.3.1. Animal research-Drawing from strong evidence that CB1 antagonists impair extinction, animal researchers have examined whether CB1 agonists can improve extinction (Fig. 1), which may have implications for exposure-based PTSD treatments (Table 3). In rats, systemic pre-extinction administration of CB1 agonists had no effect on extinction of fear-potentiated startle (Chhatwal et al., 2005). In contextual fear conditioning paradigms, a low systemic dose of the CB1 agonist WIN $(0.25 \mathrm{mg} / \mathrm{kg})$ prior to extinction training enhanced both extinction learning (Pamplona et al., 2008, 2006) and long-term retention of extinction memory in a drug-free state (Pamplona et al., 2008). However, when administered at higher doses of 1.25 or $2.5 \mathrm{mg} / \mathrm{kg}$, WIN had either no effect or it impaired extinction of contextual fear, respectively (Pamplona et al., 2006), indicating dosedependent reversals in effect.

Key regions of the fear circuitry have also been targeted to improve extinction in rats. Enhanced extinction was achieved through intra-infralimbic pre-extinction infusions of cannabidiol (a cannabinoid without psychoactive properties that is a weak CB1 antagonist) and sustained through three days of treatment and in a drug-free state (Do Monte, Souza, Bitencourt, Kroon, \& Takahashi, 2013). However, intra-infralimbic, pre-extinction CB1 agonism that enhanced extinction did not prevent reinstatement of fear after the presentation of unsignaled shocks, highlighting the transient nature of extinction memories in the face of renewed aversive experiences (Lin et al., 2009). Extinction of inhibitory avoidance was enhanced by pre-extinction CB1 agonist infusion in the CA1 (Abush \& Akirav, 2010) but not the BLA (Ganon-Elazar \& Akirav, 2009). In one case, CB1 agonist infusion in the CA1 hippocampal subregion subsequent to extinction training facilitated retention of contextual fear extinction, suggesting improved consolidation of extinction memory (de Oliveira 
Alvares, Genro, Diehl, Molina, et al., 2008). Pre-extinction local infusion of CB1 agonists in the BLA or mPFC had no effect on extinction of fear potentiated startle (Kuhnert et al., 2013).

These results, measuring a variety of fear responses in rats, indicate that it may be possible to facilitate extinction with several types of CB1 agonists. Some of the findings point to the risks of this method of intervention: high systemic doses were either ineffective or led to impairment of extinction (Chhatwal et al., 2005; Pamplona et al., 2006), and chronic administration not only impaired extinction in a drug free state but also blocked any enhancement that otherwise resulted from acute CB1 agonism (Lin, Mao, Chen, \& Gean, 2008).

3.3.2. Human research-Drawing from the animal literature on cannabinoid-enhanced extinction, similar experiments with human participants have been carried out that capitalized on the availability of synthetic, FDA-approved cannabinoids. Klumpers et al. (2012) were the first to examine the translational value of converging animal research supporting cannabinoid-enhanced fear extinction. In a fear-potentiated startle paradigm, cannabis-naïve healthy humans orally ingested synthetic THC (10 mg, dronabinol) or placebo 2 hours prior to the onset of extinction procedures so that THC availability peaked during extinction. Although there were no significant differences between groups in fearpotentiated startle, there was evidence of improved within-session extinction of skin conductance response (SCR) in the THC group. However, extinction memory retention was not improved.

In a similar study (Rabinak, Angstadt, Lyons, et al., 2013), healthy participants with fewer than 10 lifetime instances of cannabis use took a smaller dose of dronabinol $(7.5 \mathrm{mg})$ or placebo $2 \mathrm{~h}$ before extinction. In this case, THC did not improve within-session extinction of SCR, but it enhanced extinction retention on the third day relative to placebo, despite similarities in shock expectancy ratings between the two groups. In contrast, cannabidiol administered pre-or post-extinction (32 $\mathrm{mg}$, inhaled), resulted in trend-level reductions of SCRs after reinstatement, and participants who took the drug post-extinction reported lower shock expectancy ratings (Das et al., 2013).

To study neural correlates of THC augmentation, Rabinak, Angstadt, Sripada, et al. (2013) administered their extinction paradigm in an fMRI environment. While their prior findings (i.e., lower mean SCR in THC group during extinction retention test) were not replicated, participants with limited or no prior cannabis use who received $7.5 \mathrm{mg}$ of dronabinol $2 \mathrm{~h}$ prior to extinction exhibited reduced amygdala reactivity to the CS+ during early extinction training, and increased activity in the vmPFC and hippocampus to the extinguished CS+ during the extinction retention test. Together, these findings suggest effects on extinction in humans vary depending on the types and dosages of cannabinoids (THC vs. CBD), the stage of administration (pre- vs. post-extinction), and the type of response being measured (subjective reporting, SCR, startle, blood-oxygen-level dependent signal in specific brain regions). Although evidence from these human studies is promising, the paucity and inconsistency of results warrants further investigation. 
3.3.3. Alternative approaches-A compelling alternative to direct CB1 receptor agonism is the augmentation of endocannabinoid signaling via inhibition of fatty acid amide hydrolase (FAAH) and other proteins involved in the catabolism and reuptake of endocannabinoid neurotransmitters such as anandamide. Instead of globally increasing endocannabinoid receptor activation, this method increases the availability of endocannabinoid neurotransmitters in the specific regions where they have been released. In rodents, FAAH inhibition prior to extinction training has enhanced extinction learning or retention in cue (Bowers \& Ressler, 2014; Gunduz-Cinar, MacPherson, et al., 2013) and context (Laricchiuta, Centonze, \& Petrosini, 2013; Pamplona et al., 2008) conditioning, and blocked reinstatement of fear-potentiated startle (Chhatwal et al., 2005). Similar results were achieved by pre-extinction intracerebroventricular infusions (Bitencourt, Pamplona, \& Takahashi, 2008) and with targeted injections of FAAH inhibitors in the infralimbic mPFC (Lin et al., 2009), BLA (Ganon-Elazar \& Akirav, 2009; Gunduz-Cinar, MacPherson, et al., 2013), and dorsal CA1 (Abush \& Akirav, 2010).

In contrast to the inconsistent effects of treatment with exogenous cannabinoid receptor agonists, these results suggest that augmenting the action of an animal's endogenous, synaptically released cannabinoid neurotransmitters by inhibiting their breakdown during extinction training may be more effective in strengthening extinction memory. Although this approach has yet to be extended to humans, healthy participants with a low-expressing variant of the FAAH gene (implying augmented endocannabinoid transmitter levels) scored lower on measures of stress-reactivity, and displayed significantly faster rate of decrease in amygdala activation to threatening faces, suggesting a role for endocannabinoid transmitters in habituation to threat cues, which may be impaired in PTSD (Gunduz-Cinar, MacPherson, et al., 2013).

\section{Discussion}

Although PTSD research has predominantly focused on those who have already developed the disorder, the use of conditioning and extinction paradigms with animals and, more recently, humans, has made it possible to examine neurobiological factors involved before, during, and after exposure to stress. At every stage of the process (see Fig. 1), emerging data suggest the ECS plays a key role.

First, the reviewed literature provides compelling evidence that disruption of CB1 signaling in rodents impairs fear extinction. In healthy humans, genetic variability in CB1 receptor availability is associated with the degree of fear extinction. There is emerging evidence of abnormal CB1 receptor density in individuals with PTSD; however, the findings with endocannabinoid neurotransmitters have been contradictory, with results of either elevated or diminished plasma levels of anandamide in PTSD samples relative to healthy controls. Clearly, further research is necessary to determine whether these types of disruptions in the ECS, which may result from genetic variation or environmental factors, put individuals at risk for developing PTSD. This would have practical implications for screening and preventive care, especially among subpopulations with higher risk of exposure to trauma (e.g., soldiers, firefighters, police, first responders). 
Although a small subset of individuals exposed to trauma develop PTSD, the debilitating course and exorbitant societal costs associated with the disorder require the consideration of intervening shortly after trauma but before the development of PTSD. Avenues for cognitive intervention have been inconsistent (Van Emmerik, Kamphuis, Hulsbosch, \& Emmelkamp, 2002). In fact, it has been suggested that certain types of memory recall immediately post trauma may have an iatrogenic effect (Mayou, Ehlers, \& Hobbs, 2000). However, pharmacologic research on memory consolidation and reconsolidation has illuminated potential methods for such an approach. Currently there is only limited evidence that the ECS can be targeted as a preventive measure. Although CB1 agonists were inconsistent in blocking the consolidation of fearful memories in rodents, the same intervention after brief reactivation of the memory was more dependable in weakening fearful associations. Although this approach with cannabinoids has not been extended to humans, a few studies with healthy humans have examined reconsolidation in the context of fear conditioning with other compounds, achieving success with the $\beta$-adrenergic receptor antagonist propranolol (Kindt, Soeter, \& Vervliet, 2009). However, propranolol failed to prevent PTSD when administered shortly after trauma (Hoge et al., 2012). This highlights one of the challenges of translation from preclinical to clinical studies, which may be a potential pitfall of extending this line of research to include targeting the ECS.

Lastly, the ECS is a potential avenue for enhancing exposure-based therapy for PTSD.

Although in a nascent stage of science, there is promising converging evidence in the animal and human research of enhanced extinction learning and retention through the targeting of the ECS. Notably, this approach only worked in conjunction with extinction training; CB1 receptor agonism on its own had no effect. Although much work remains to be done to translate these models to clinical application in the treatment of PTSD, the evidence suggests that for at least certain symptoms, cannabis may be only beneficial as an adjunct to exposure therapy. For these purposes, FAAH inhibitors that prolong the availability of the organism's endogenous cannabinoid neurotransmitters may be advantageous in both their selectivity of desired effects and reduced risk of adverse effects relative to direct cannabinoid agonists (Cravatt \& Lichtman, 2003). Moreover, rodent research has demonstrated ECS interactions with transient receptor potential vanilloid type 1 (Genro, de Oliveira Alvares, \& Quillfeldt, 2012; Laricchiuta et al., 2013; Marsch et al., 2007), polyunsaturated fatty acids (Yamada, Takeo, Koppensteiner, Wada, \& Sekiguchi, 2014), and dopaminergic receptors (Terzian et al., 2011). These are complex interactions that need to be evaluated in humans.

Several areas of research need to be expanded in order to determine if approaches targeting the ECS would impact the efficacy of exposure therapy for PTSD. Experiments with human subjects need to be expanded to examine quantity, timing, and duration of administration, dosing (which has led to reversal of effects in animal studies), and a cost-benefit analysis of the available agents that includes comparisons of side effects and implications of long-term use. Sex differences in both ECS properties and fear processing need further clarification, as lower plasma levels of the endocannabinoid neurotransmitter anandamide have been measured in human and rodent females (Neumeister et al., 2013; Reich, Taylor, \& McCarthy, 2009), and extinction deficits have been moderated by sex in patients with 
PTSD, with males demonstrating greater impairment in extinction retention relative to females (Shvil et al., 2014). Replications of experimental results with ECS manipulations need to be extended to subjects with PTSD in studies with larger samples so that individual differences can be explored. This would represent a further translational step toward clinical trials of exposure therapy with a cannabinoid component.

Clinical case reports (Fraser, 2009; Passie, Emrich, Karst, Brandt, \& Halpern, 2012), a small open label study (Roitman, Mechoulam, Cooper-Kazaz, \& Shalev, 2014), and a review of patient charts in New Mexico's Medical Cannabis Program (Greer, Grob, \& Halberstadt, 2014) suggest some individuals with PTSD get symptom relief from cannabis. However, epidemiologic findings showing high rates of comorbid cannabis dependence among individuals with PTSD (Galatzer-Levy, Nickerson, Litz, \& Marmar, 2013; Ruglass, LopezCastro, Cheref, Papini, \& Hien, 2014) may point to a subpopulation that continues to struggle with PTSD despite an attempt to alleviate their symptoms with marijuana. Cooccurring PTSD and substance use treatments have successfully targeted both disorders (Hien, Cohen, Miele, Litt, \& Capstick, 2004; Hien et al., 2010), but for those who selfmedicate, temporary relief may come at the cost of long-term benefit, as overuse of the drug can lead to downregulation of CB1 receptors (Hirvonen et al., 2012; Neumeister, 2013), possibly resulting in impaired extinction of symptoms. Moreover, meta-analytic studies suggest cannabis use in adolescence increases the risk of psychosis and schizophrenia (Large, Sharma, Compton, Slade, \& Nielssen, 2011; Semple, McIntosh, \& Lawrie, 2005), and a variety of poor psychosocial outcomes (Hall, 2014) underscoring the need for a thorough evaluation of the drug. As the rapid sociopolitical shift leads to expanded legalization of marijuana, a scientifically informed approach that builds on translational models is crucial in order to fully understand the role of the ECS in the development and treatment of PTSD.

\section{Acknowledgments}

S. Papini receives funding from NIDA R25DA035161-01; D. A. Hien receives funding from NIDA R01DA023187-01, U10DA13035, AA014341, and NIDA R25DA035161-01; E. Shvil receives funding from T32 MH015144-34 and NARSAD; Y. Neria receives funding from NIMH R01MH072833, NIDA R25DA035161, and NHLBI R01HL117832.

\section{References}

Abush H, Akirav I. Cannabinoids modulate hippocampal memory and plasticity. Hippocampus. 2010; 20(10):1126-1138. http://dx.doi.org/10.1002/hipo.20711. [PubMed: 19830813]

Admon R, Milad MR, Hendler T. A causal model of post-traumatic stress disorder: Disentangling predisposed from acquired neural abnormalities. Trends in Cognitive Sciences. 2013; 17(7):337347. [PubMed: 23768722]

Akirav I. The role of cannabinoids in modulating emotional and non-emotional memory processes in the hippocampus. Frontiers in Behavioral Neuroscience. 2011; 5:34. http://dx.doi.org/10.3389/ fnbeh.2011.00034. [PubMed: 21734875]

Amano T, Unal CT, Paré D. Synaptic correlates of fear extinction in the amygdala. Nature Neuroscience. 2010; 13(4):489-494.

American Psychiatric Association. Diagnostic and statistical manual of mental disorders. 5. Arlington, VA: American Psychiatric Publishing; 2013. 
Atsak P, Hauer D, Campolongo P, Schelling G, McGaugh JL, Roozendaal B. Glucocorticoids interact with the hippocampal endocannabinoid system in impairing retrieval of contextual fear memory. Proceedings of the National Academy of Sciences. 2012; 109(9):3504-3509.

Bitencourt RM, Pamplona FA, Takahashi RN. Facilitation of contextual fear memory extinction and anti-anxiogenic effects of AM404 and cannabidiol in conditioned rats. European Neuropsychopharmacology. 2008; 18(12):849-859. http://dx.doi.org/10.1016/j.euroneuro. 2008.07.001. [PubMed: 18706790]

Bitterman M, Holtzman WH. Conditioning and extinction of the galvanic skin response as a function of anxiety. Journal of Abnormal and Social Psychology. 1952; 47(3):615.

Bouton M, Mineka S, Barlow D. A modern learning theory perspective on the etiology of panic disorder. Psychological Review. 2001; 108(1):4-32. [PubMed: 11212632]

Bouton ME, García-Gutiérrez A, Zilski J, Moody EW. Extinction in multiple contexts does not necessarily make extinction less vulnerable to relapse. Behaviour Research and Therapy. 2006; 44(7):983-994. [PubMed: 16198302]

Bowers, ME.; Ressler, KJ. Interaction between the cholecystokinin and endogenous cannabinoid systems in cued fear expression and extinction retention. Neuropsychopharmacology. 2014. http:// dx.doi.org/10.1038/npp.2014.225

Breslau N. The epidemiology of trauma, PTSD, and other posttrauma disorders. Trauma, Violence, \& Abuse. 2009; 10(3):198-210.

Bucherelli C, Baldi E, Mariottini C, Passani MB, Blandina P. Aversive memory reactivation engages in the amygdala only some neurotransmitters involved in consolidation. Learning and Memory. 2006; 13(4):426-430. [PubMed: 16882859]

Campolongo P, Roozendaal B, Trezza V, Hauer D, Schelling G, McGaugh JL, et al. Endocannabinoids in the rat basolateral amygdala enhance memory consolidation and enable glucocorticoid modulation of memory. Proceedings of the National Academy of Sciences. 2009; 106(12):4888 4893.

Cannich A, Wotjak CT, Kamprath K, Hermann H, Lutz B, Marsicano G. CB1 cannabinoid receptors modulate kinase and phosphatase activity during extinction of conditioned fear in mice. Learning and Memory. 2004; 11(5):625-632. http://dx.doi.org/10.1101/lm.77904. [PubMed: 15466318]

Chhatwal JP, Davis M, Maguschak KA, Ressler KJ. Enhancing cannabinoid neurotransmission augments the extinction of conditioned fear. Neuropsychopharmacology. 2005; 30(3):516-524. http://dx.doi.org/10.1038/sj.npp.1300655. [PubMed: 15637635]

Chhatwal JP, Gutman AR, Maguschak KA, Bowser ME, Yang Y, Davis M, et al. Functional interactions between endocannabinoid and CCK neurotransmitter systems may be critical for extinction learning. Neuropsychopharmacology. 2009; 34(2):509-521. http://dx.doi.org/10.1038/ npp.2008.97. [PubMed: 18580872]

Christensen R, Kristensen PK, Bartels EM, Bliddal H, Astrup A. Efficacy and safety of the weight-loss drug rimonabant: A meta-analysis of randomised trials. The Lancet. 2007; 370(9600):1706-1713.

Cordero MI, Venero C, Kruyt ND, Sandi C. Prior exposure to a single stress session facilitates subsequent contextual fear conditioning in rats: Evidence for a role of corticosterone. Hormones and Behavior. 2003; 44(4):338-345. [PubMed: 14613728]

Cravatt BF, Lichtman AH. Fatty acid amide hydrolase: An emerging therapeutic target in the endocannabinoid system. Current Opinion in Chemical Biology. 2003; 7(4):469-475. [PubMed: 12941421]

Crippa JA, Zuardi AW, Martin-Santos R, Bhattacharyya S, Atakan Z, McGuire P, et al. Cannabis and anxiety: A critical review of the evidence. Human Psychopharmacology. 2009; 24(7):515-523. http://dx.doi.org/10.1002/hup.1048. [PubMed: 19693792]

Das RK, Kamboj SK, Ramadas M, Yogan K, Gupta V, Redman E, et al. Cannabidiol enhances consolidation of explicit fear extinction in humans. Psychopharmacology. 2013; 226(4):781-792. http://dx.doi.org/10.1007/s00213-012-2955-y. [PubMed: 23307069]

Davis M. Neural systems involved in fear and anxiety measured with fear-potentiated startle. American Psychologist. 2006; 61(8):741. [PubMed: 17115806]

de Bitencourt RM, Pamplona FA, Takahashi RN. A current overview of cannabinoids and glucocorticoids in facilitating extinction of aversive memories: Potential extinction enhancers. 
Neuropharmacology. 2013; 64:389-395. http://dx.doi.org/10.1016/j.neuropharm.2012.05.039. [PubMed: 22687521]

de Oliveira Alvares L, de Oliveira LF, Camboim C, Diehl F, Genro BP, Lanziotti VB, et al. Amnestic effect of intrahippocampal AM251, a CB1-selective blocker, in the inhibitory avoidance, but not in the open field habituation task, in rats. Neurobiology of Learning and Memory. 2005; 83(2):119124. [PubMed: 15721795]

de Oliveira Alvares L, Genro BP, Diehl F, Molina VA, Quillfeldt JA. Opposite action of hippocampal CB1 receptors in memory reconsolidation and extinction. Neuroscience. 2008; 154(4):1648-1655. http://dx.doi.org/10.1016/j.neuroscience.2008.05.005. [PubMed: 18554811]

de Oliveira Alvares L, Genro BP, Diehl F, Quillfeldt JA. Differential role of the hippocampal endocannabinoid system in the memory consolidation and retrieval mechanisms. Neurobiology of Learning and Memory. 2008; 90(1):1-9. [PubMed: 18342551]

Delamater AR. Experimental extinction in pavlovian conditioning: Behavioural and neuroscience perspectives. Quarterly Journal of Experimental Psychology. B: Comparative and Physiological Psychology. 2004; 57(2):97-132. http://dx.doi.org/10.1080/02724990344000097.

Di Marzo V, Bifulco M, De Petrocellis L. The endocannabinoid system and its therapeutic exploitation. Nature Reviews Drug Discovery. 2004; 3(9):771-784. http://dx.doi.org/10.1038/ nrd1495.

Do Monte FH, Souza RR, Bitencourt RM, Kroon JA, Takahashi RN. Infusion of cannabidiol into infralimbic cortex facilitates fear extinction via CB1 receptors. Behavioural Brain Research. 2013; 250:23-27. http://dx.doi.org/10.1016/j.bbr.2013.04.045. [PubMed: 23643693]

Dubreucq S, Matias I, Cardinal P, Haring M, Lutz B, Marsicano G, et al. Genetic dissection of the role of cannabinoid type-1 receptors in the emotional consequences of repeated social stress in mice. Neuropsychopharmacology. 2012; 37(8):1885-1900. http://dx.doi.org/10.1038/npp.2012.36. [PubMed: 22434220]

Falls WA, Miserendino MJ, Davis M. Extinction of fear-potentiated startle: Blockade by infusion of an nmda antagonist into the amygdala. Journal of Neuroscience. 1992; 12(3):854-863. [PubMed: 1347562]

Fani N, Tone EB, Phifer J, Norrholm SD, Bradley B, Ressler KJ, et al. Attention bias toward threat is associated with exaggerated fear expression and impaired extinction in PTSD. Psychological Medicine. 2012; 42(03):533-543. [PubMed: 21854700]

Fitzgerald PJ, Seemann JR, Maren S. Can fear extinction be enhanced? A review of pharmacological and behavioral findings. Brain Research Bulletin. 2014; 105:46-60. [PubMed: 24374101]

Foa, E.; Hembree, E.; Rothbaum, BO. Prolonged exposure therapy for PTSD: Emotional processing of traumatic experiences therapist guide. London: Oxford University Press; 2007.

Fraser GA. The use of a synthetic cannabinoid in the management of treatment-resistant nightmares in posttraumatic stress disorder (PTSD). CNS Neuroscience \& Therapeutics. 2009; 15(1):84-88. [PubMed: 19228182]

Galatzer-Levy IR, Bonanno GA, Bush DE, LeDoux JE. Heterogeneity in threat extinction learning: Substantive and methodological considerations for identifying individual difference in response to stress. Frontiers in Behavioral Neuroscience. 2013; 7:55. [PubMed: 23754992]

Galatzer-Levy IR, Nickerson A, Litz BT, Marmar CR. Patterns of lifetime PTSD comorbidity: A latent class analysis. Depression and Anxiety. 2013; 30(5):489-496. [PubMed: 23281049]

Ganon-Elazar E, Akirav I. Cannabinoid receptor activation in the basolateral amygdala blocks the effects of stress on the conditioning and extinction of inhibitory avoidance. Journal of Neuroscience. 2009; 29(36):11078-11088. http://dx.doi.org/10.1523/JNEUROSCI.1223-09.2009. [PubMed: 19741114]

Ganon-Elazar E, Akirav I. Cannabinoids prevent the development of behavioral and endocrine alterations in a rat model of intense stress. Neuropsychopharmacology. 2012; 37(2):456-466. http://dx.doi.org/10.1038/npp.2011.204. [PubMed: 21918506]

Ganon-Elazar E, Akirav I. Cannabinoids and traumatic stress modulation of contextual fear extinction and gr expression in the amygdala-hippocampal-prefrontal circuit. Psychoneuroendocrinology. 2013; 38(9):1675-1687. http://dx.doi.org/10.1016/j.psyneuen.2013.01.014. [PubMed: 23433741] 
Garfinkel SN, Abelson JL, King AP, Sripada RK, Wang X, Gaines LM, et al. Impaired contextual modulation of memories in PTSD: An fmri and psychophysiological study of extinction retention and fear renewal. Journal of Neuroscience. 2014; 34(40):13435-13443. [PubMed: 25274821]

Garfinkel SN, Liberzon I. Neurobiology of PTSD: A review of neuroimaging findings. Psychiatric Annals. 2009; 39(6):370-381. http://dx.doi.org/10.3928/00485713-20090527-01.

Genro BP, de Oliveira Alvares L, Quillfeldt JA. Role of trpv1 in consolidation of fear memories depends on the averseness of the conditioning procedure. Neurobiology of Learning and Memory. 2012; 97(4):355-360. [PubMed: 22270459]

Glass M, Dragunow M, Faull RLM. Cannabinoid receptors in the human brain: A detailed anatomical and quantitative autoradiographic study in the fetal, neonatal and adult human brain. Neuroscience. 1997; 77(2):299-318. [PubMed: 9472392]

Greer GR, Grob CS, Halberstadt AL. PTSD symptom reports of patients evaluated for the new mexico medical cannabis program. Journal of Psychoactive Drugs. 2014; 46(1):73-77. [PubMed: 24830188]

Grillon C. Startle reactivity and anxiety disorders: Aversive conditioning, context, and neurobiology. Biological Psychiatry. 2002; 52(10):958-975. [PubMed: 12437937]

Grillon C, Morgan CA III. Fear-potentiated startle conditioining to explicit and contextual cues in gulf war veterans with posttraumatic stress disorder. Journal of Abnormal Psychology. 1999; 108(1): 134-142. [PubMed: 10066999]

Gunduz-Cinar O, Hill MN, McEwen BS, Holmes A. Amygdala faah and anandamide: Mediating protection and recovery from stress. Trends in Pharmacological Sciences. 2013; 34(11):637-644. [PubMed: 24325918]

Gunduz-Cinar O, MacPherson KP, Cinar R, Gamble-George J, Sugden K, Williams B, et al. Convergent translational evidence of a role for anandamide in amygdala-mediated fear extinction, threat processing and stress-reactivity. Molecular Psychiatry. 2013; 18(7):813-823. http:// dx.doi.org/10.1038/mp.2012.72. [PubMed: 22688188]

Guthrie RM, Bryant RA. Extinction learning before trauma and subsequent posttraumatic stress. Psychosomatic Medicine. 2006; 68(2):307-311. http://dx.doi.org/10.1097/01.psy. 0000208629.67653.cc, 68/2/307 [pii]. [PubMed: 16554398]

Hall, W. What has research over the past two decades revealed about the adverse health effects of recreational cannabis use?. Addiction, Advance online publication. 2014. http://dx.doi.org/ 10.1111/add.12703

Hauer D, Schelling G, Gola H, Campolongo P, Morath J, Roozendaal B, et al. Plasma concentrations of endocannabinoids and related primary fatty acid amides in patients with post-traumatic stress disorder. PLoS ONE. 2013; 8(5):e62741. http://dx.doi.org/10.1371/journal.pone.0062741. [PubMed: 23667516]

Heitland I, Klumpers F, Oosting RS, Evers DJ, Leon Kenemans J, Baas JM. Failure to extinguish fear and genetic variability in the human cannabinoid receptor 1. Translational Psychiatry. 2012; 2:e162. http://dx.doi.org/10.1038/tp.2012.90. [PubMed: 23010766]

Hettema JM, Annas P, Neale MC, Kendler KS, Fredrikson M. A twin study of the genetics of fear conditioning. Archives of General Psychiatry. 2003; 60(7):702-708. [PubMed: 12860774]

Hien DA, Cohen LR, Miele GM, Litt LC, Capstick C. Promising treatments for women with comorbid PTSD and substance use disorders. American Journal of Psychiatry. 2004; 161(8):1426-1432. [PubMed: 15285969]

Hien DA, Jiang H, Campbell AN, Hu M, Miele GM, Cohen LR, et al. Do treatment improvements in PTSD severity affect substance use outcomes? A secondary analysis from a randomized clinical trial in nida's clinical trials network. American Journal of Psychiatry. 2010; 167(1):95-101. [PubMed: 19917596]

Hill MN, Patel S. Translational evidence for the involvement of the endocannabinoid system in stressrelated psychiatric illnesses. Biology of Mood \& Anxiety Disorders. 2013; 3(1):19. [PubMed: 24286185]

Hirvonen J, Goodwin R, Li C, Terry G, Zoghbi S, Morse C, et al. Reversible and regionally selective downregulation of brain cannabinoid $\mathrm{CB} 1$ receptors in chronic daily cannabis smokers. Molecular Psychiatry. 2012; 17(6):642-649. [PubMed: 21747398] 
Hofmann SG. Cognitive processes during fear acquisition and extinction in animals and humans: Implications for exposure therapy of anxiety disorders. Clinical Psychology Review. 2008; 28(2): 199-210. [PubMed: 17532105]

Hoge EA, Worthington JJ, Nagurney JT, Chang Y, Kay EB, Feterowski CM, et al. Effect of acute posttrauma propranolol on PTSD outcome and physiological responses during script-driven imagery. CNS Neuroscience \& Therapeutics. 2012; 18(1):21-27. [PubMed: 22070357]

Inslicht SS, Metzler TJ, Garcia NM, Pineles SL, Milad MR, Orr SP, et al. Sex differences in fear conditioning in posttraumatic stress disorder. Journal of Psychiatric Research. 2013; 47(1):64-71. [PubMed: 23107307]

Izquierdo A, Wellman CL, Holmes A. Brief uncontrollable stress causes dendritic retraction in infralimbic cortex and resistance to fear extinction in mice. Journal of Neuroscience. 2006; 26(21): 5733-5738. [PubMed: 16723530]

Jacob W, Marsch R, Marsicano G, Lutz B, Wotjak CT. Cannabinoid CB1 receptor deficiency increases contextual fear memory under highly aversive conditions and long-term potentiation in vivo. Neurobiology of Learning and Memory. 2012; 98(1):47-55. [PubMed: 22579951]

Jamali-Raeufy N, Nasehi M, Zarrindast MR. Influence of n-methyl d-aspartate receptor mechanism on win55, 212-2-induced amnesia in rat dorsal hippocampus. Behavioural Pharmacology. 2011; 22(7):645-654. [PubMed: 21918382]

Jovanovic T, Ressler KJ. How the neurocircuitry and genetics of fear inhibition may inform our understanding of PTSD. American Journal of Psychiatry. 2010; 167(6):648-662. [PubMed: 20231322]

Kamprath K, Marsicano G, Tang J, Monory K, Bisogno T, Di Marzo V, et al. Cannabinoid CB1 receptor mediates fear extinction via habituation-like processes. Journal of Neuroscience. 2006; 26(25):6677-6686. http://dx.doi.org/10.1523/JNEUROSCI.0153-06.2006. [PubMed: 16793875]

Kamprath K, Plendl W, Marsicano G, Deussing JM, Wurst W, Lutz B, et al. Endocannabinoids mediate acute fear adaptation via glutamatergic neurons independently of corticotropin-releasing hormone signaling. Genes, Brain and Behavior. 2009; 8(2):203-211.

Kaplan GB, Moore KA. The use of cognitive enhancers in animal models of fear extinction. Pharmacology, Biochemistry and Behavior. 2011; 99(2):217-228. http://dx.doi.org/10.1016/j.pbb. 2011.01.009.

Kindt M, Soeter M, Vervliet B. Beyond extinction: Erasing human fear responses and preventing the return of fear. Nature Neuroscience. 2009; 12(3):256-258.

Klumpers F, Denys D, Kenemans JL, Grillon C, van der Aart J, Baas JM. Testing the effects of delta9THC and d-cycloserine on extinction of conditioned fear in humans. Journal of Psychopharmacology. 2012; 26(4):471-478. http://dx.doi.org/10.1177/0269881111431624. [PubMed: 22351380]

Korem, N.; Akirav, I. Cannabinoids prevent the effects of a footshock followed by situational reminders on emotional processing. Neuropsychopharmacology. 2014. http://dx.doi.org/10.1038/ npp.2014.132

Kucerova J, Tabiova K, Drago F, Micale V. Therapeutic potential of cannabinoids in schizophrenia. Recent Patents on CNS Drug Discovery. 2014; 9:13-25. [PubMed: 24605939]

Kuhnert S, Meyer C, Koch M. Involvement of cannabinoid receptors in the amygdala and prefrontal cortex of rats in fear learning, consolidation, retrieval and extinction. Behavioural Brain Research. 2013; 250:274-284. http://dx.doi.org/10.1016/j.bbr.2013.05.002. [PubMed: 23702112]

Large M, Sharma S, Compton MT, Slade T, Nielssen O. Cannabis use and earlier onset of psychosis: A systematic meta-analysis. Archives of General Psychiatry. 2011; 68(6):555-561. [PubMed: 21300939]

Laricchiuta D, Centonze D, Petrosini L. Effects of endocannabinoid and endovanilloid systems on aversive memory extinction. Behavioural Brain Research. 2013; 256:101-107. http://dx.doi.org/ 10.1016/j.bbr.2013.08.010. [PubMed: 23948212]

LeDoux JE. Emotion circuits in the brain. Science of Mental Health: Fear and Anxiety. 2001; 259

Lee JLC, Milton AL, Everitt BJ. Reconsolidation and extinction of conditioned fear: Inhibition and potentiation. Journal of Neuroscience. 2006; 26(39):10051-10056. [PubMed: 17005868] 
Lin HC, Mao SC, Chen PS, Gean PW. Chronic cannabinoid administration in vivo compromises extinction of fear memory. Learning and Memory. 2008; 15(12):876-884. http://dx.doi.org/ 10.1101/lm.1081908. [PubMed: 19050159]

Lin HC, Mao SC, Gean PW. Effects of intra-amygdala infusion of CB1 receptor agonists on the reconsolidation of fear-potentiated startle. Learning and Memory. 2006; 13(3):316-321. http:// dx.doi.org/10.1101/lm.217006. [PubMed: 16705137]

Lin HC, Mao SC, Su CL, Gean PW. The role of prefrontal cortex CB1 receptors in the modulation of fear memory. Cerebral Cortex. 2009; 19(1):165-175. http://dx.doi.org/10.1093/cercor/bhn075. [PubMed: 18477688]

Lin QS, Yang Q, Liu DD, Sun Z, Dang H, Liang J, et al. Hippocampal endocannabinoids play an important role in induction of long-term potentiation and regulation of contextual fear memory formation. Brain Research Bulletin. 2011; 86(3):139-145. [PubMed: 21801815]

Lissek S, Powers AS, McClure EB, Phelps EA, Woldehawariat G, Grillon C, et al. Classical fear conditioning in the anxiety disorders: A meta-analysis. Behaviour Research and Therapy. 2005; 43(11):1391-1424. http://dx.doi.org/10.1016/j.brat.2004.10.007. [PubMed: 15885654]

Lu KT, Walker DL, Davis M. Mitogen-activated protein kinase cascade in the basolateral nucleus of amygdala is involved in extinction of fear-potentiated startle. Journal of Neuroscience. 2001; 21:1-5.

Lutz B. The endocannabinoid system and extinction learning. Molecular Neurobiology. 2007; 36(1): 92-101. http://dx.doi.org/10.1007/s12035-007-8004-x. [PubMed: 17952654]

Maćkowiak M, Chocyk A, Dudys D, Wedzony K. Activation of CB1 cannabinoid receptors impairs memory consolidation and hippocampal polysialylated neural cell adhesion molecule expression in contextual fear conditioning. Neuroscience. 2009; 158(4):1708-1716. [PubMed: 19110037]

Marsch R, Foeller E, Rammes G, Bunck M, Kössl M, Holsboer F, et al. Reduced anxiety, conditioned fear, and hippocampal long-term potentiation in transient receptor potential vanilloid type 1 receptor-deficient mice. Journal of Neuroscience. 2007; 27(4):832-839. [PubMed: 17251423]

Marschner A, Kalisch R, Vervliet B, Vansteenwegen D, Buchel C. Dissociable roles for the hippocampus and the amygdala in human cued versus context fear conditioning. Journal of Neuroscience. 2008; 28(36):9030-9036. http://dx.doi.org/10.1523/JNEUROSCI.1651-08.2008. [PubMed: 18768697]

Marsicano G, Wotjak CT, Azad SC, Bisogno T, Rammes G, Cascio MG, et al. The endogenous cannabinoid system controls extinction of aversive memories. Nature. 2002; 418(6897):530-534. [PubMed: 12152079]

Mayou RA, Ehlers A, Hobbs M. Psychological debriefing for road traffic accident victims three-year follow-up of a randomised controlled trial. British Journal of Psychiatry. 2000; 176(6):589-593. [PubMed: 10974967]

Mazzola C, Medalie J, Scherma M, Panlilio LV, Solinas M, Tanda G, et al. Fatty acid amide hydrolase (faah) inhibition enhances memory acquisition through activation of ppar-a nuclear receptors. Learning and Memory. 2009; 16(5):332-337. [PubMed: 19403796]

McGaugh JL. Memory-A century of consolidation. Science. 2000; 287(5451):248-251. [PubMed: 10634773]

Micale V, Di Marzo V, Sulcova A, Wotjak CT, Drago F. Endocannabinoid system and mood disorders: Priming a target for new therapies. Pharmacology and Therapeutics. 2013; 138(1):1837. http://dx.doi.org/10.1016/j.pharmthera.2012.12.002. [PubMed: 23261685]

Milad MR, Orr SP, Lasko NB, Chang Y, Rauch SL, Pitman RK. Presence and acquired origin of reduced recall for fear extinction in PTSD: Results of a twin study. Journal of Psychiatry Research. 2008; 42(7):515-520. http://dx.doi.org/10.1016/j.jpsychires.2008.01.017.

Milad MR, Pitman RK, Ellis CB, Gold AL, Shin LM, Lasko NB, et al. Neurobiological basis of failure to recall extinction memory in posttraumatic stress disorder. Biological Psychiatry. 2009; 66(12): 1075-1082. [PubMed: 19748076]

Milad MR, Quirk GJ. Fear extinction as a model for translational neuroscience: Ten years of progress. Annual Review of Psychology. 2012; 63:129-151. 
Mishima K, Egashira N, Hirosawa N, Fujii M, Matsumoto Y, Iwasaki K, et al. Characteristics of learning and memory impairment induced by delta9-tetrahydrocannabinol in rats. Japanese Journal of Pharmacology. 2001; 87(4):297-308. [PubMed: 11829149]

Monfils MH, Cowansage KK, Klann E, LeDoux JE. Extinction-reconsolidation boundaries: Key to persistent attenuation of fear memories. Science. 2009; 324(5929):951-955. [PubMed: 19342552]

Moore NL, Gauchan S, Genovese RF. Adolescent traumatic stress experience results in less robust conditioned fear and post-extinction fear cue responses in adult rats. Pharmacology Biochemistry and Behavior. 2014; 120:17-24.

Moore TH, Zammit S, Lingford-Hughes A, Barnes TR, Jones PB, Burke M, et al. Cannabis use and risk of psychotic or affective mental health outcomes: A systematic review. Lancet. 2007; 370(9584):319-328. [PubMed: 17662880]

Moshfegh A, Babaei P, Oryan S, Soltani B, Zarrindast MR. Involvement of dorsal hippocampal a1adrenergic receptors in the effect of WIN55, 212-2 on memory retrieval in inhibitory avoidance task. Neuroscience Letters. 2011; 489(2):69-73. [PubMed: 20691753]

Myers K, Davis M. Mechanisms of fear extinction. Molecular Psychiatry. 2007; 12(2):120-150. [PubMed: 17160066]

Myers KM, Davis M. Behavioral and neural analysis of extinction. Neuron. 2002; 36:567-584. [PubMed: 12441048]

Nader K, Hardt O. A single standard for memory: The case for reconsolidation. Nature Reviews Neuroscience. 2009; 10(3):224-234.

Nader K, Schafe GE, Le Doux JE. Fear memories require protein synthesis in the amygdala for reconsolidation after retrieval. Nature. 2000; 406(6797):722-726. [PubMed: 10963596]

Nasehi M, Sahebgharani M, Haeri-Rohani A, Zarrindast MR. Effects of cannabinoids infused into the dorsal hippocampus upon memory formation in 3-days apomorphine-treated rats. Neurobiology of Learning and Memory. 2009; 92(3):391-399. [PubMed: 19450698]

Neria Y, Wickramaratne P, Olfson M, Gameroff MJ, Pilowsky DJ, Lantigua R, et al. Mental and physical health consequences of the september 11, $2001(9 / 11)$ attacks in primary care: A longitudinal study. Journal of Traumatic Stress. 2013; 26(1):45-55. http://dx.doi.org/10.1002/jts. 21767. [PubMed: 23319335]

Neumeister A. The endocannabinoid system provides an avenue for evidence-based treatment development for PTSD. Depression and Anxiety. 2013; 30(2):93-96. [PubMed: 23225490]

Neumeister A, Normandin MD, Pietrzak RH, Piomelli D, Zheng MQ, Gujarro-Anton A, et al. Elevated brain cannabinoid CB1 receptor availability in post-traumatic stress disorder: A positron emission tomography study. Molecular Psychiatry. 2013; 18(9):1034-1040. http://dx.doi.org/ 10.1038/mp.2013.61. [PubMed: 23670490]

Niyuhire F, Varvel SA, Thorpe AJ, Stokes RJ, Wiley JL, Lichtman AH. The disruptive effects of the CB1 receptor antagonist rimonabant on extinction learning in mice are task-specific. Psychopharmacology. 2007; 191(2):223-231. [PubMed: 17211653]

Norrholm SD, Jovanovic T, Olin IW, Sands LA, Bradley B, Ressler KJ. Fear extinction in traumatized civilians with posttraumatic stress disorder: Relation to symptom severity. Biological Psychiatry. 2011; 69(6):556-563. [PubMed: 21035787]

Orr SP, Milad MR, Metzger LJ, Lasko NB, Gilbertson MW, Pitman RK. Effects of beta blockade, PTSD diagnosis, and explicit threat on the extinction and retention of an aversively conditioned response. Biological Psychology. 2006; 73(3):262-271. [PubMed: 16828533]

Pamplona FA, Bitencourt RM, Takahashi RN. Short- and long-term effects of cannabinoids on the extinction of contextual fear memory in rats. Neurobiology of Learning and Memory. 2008; 90(1):290-293. http://dx.doi.org/10.1016/j.nlm.2008.04.003. [PubMed: 18486502]

Pamplona FA, Prediger RD, Pandolfo P, Takahashi RN. The cannabinoid receptor agonist win 55,212-2 facilitates the extinction of contextual fear memory and spatial memory in rats. Psychopharmacology. 2006; 188(4):641-649. http://dx.doi.org/10.1007/s00213-006-0514-0. [PubMed: 16947018]

Passie T, Emrich HM, Karst M, Brandt SD, Halpern JH. Mitigation of post-traumatic stress symptoms by cannabis resin: A review of the clinical and neurobiological evidence. Drug Testing and Analysis. 2012; 4(7-8):649-659. [PubMed: 22736575] 
Pavlov, I. Conditioned reflex. London: Oxford University Press; 1927.

Pedreira, MaE; Maldonado, H. Protein synthesis subserves reconsolidation or extinction depending on reminder duration. Neuron. 2003; 38(6):863-869. [PubMed: 12818173]

Phillips RG, LeDoux JE. Differential contribution of amygdala and hippocampus to cued and contextual fear conditioning. Behavioral Neuroscience. 1992; 106(2):274-285. [PubMed: 1590953]

Piri M, Zarrindast MR. Modulation of win55, 212-2 state-dependent memory by a2-adrenergic receptors of the dorsal hippocampus. Archives of Iranian Medicine (AIM). 2011; 14(6):389-395.

Plendl W, Wotjak CT. Dissociation of within- and between-session extinction of conditioned fear. Journal of Neuroscience. 2010; 30(14):4990-4998. http://dx.doi.org/10.1523/JNEUROSCI. 6038-09.2010. [PubMed: 20371819]

Powers MB, Halpern JM, Ferenschak MP, Gillihan SJ, Foa EB. A meta-analytic review of prolonged exposure for post-traumatic stress disorder. Clinical Psychology Review. 2010; 30(6):635-641. http://dx.doi.org/10.1016/j.cpr.2010.04.007. [PubMed: 20546985]

Quirk GJ, Gehlert DR. Inhibition of the amygdala: Key to pathological states? Annual New York Academy of Sciences. 2003; 985:263-272.

Quirk GJ, Mueller D. Neural mechanisms of extinction learning and retrieval. Neuropsychopharmacology. 2008; 33(1):56-72. http://dx.doi.org/10.1038/sj.npp.1301555. [PubMed: 17882236]

Rabinak, CA.; Angstadt, M.; Lyons, M.; Mori, S.; Milad, MR.; Liberzon, I., et al. Cannabinoid modulation of prefrontal-limbic activation during fear extinction learning and recall in humans. Neurobiology of Learning and Memory. 2013. http://dx.doi.org/10.1016/j.nlm.2013.09.009

Rabinak CA, Angstadt M, Sripada CS, Abelson JL, Liberzon I, Milad MR, et al. Cannabinoid facilitation of fear extinction memory recall in humans. Neuropharmacology. 2013; 64:396-402. http://dx.doi.org/10.1016/j.neuropharm.2012.06.063. [PubMed: 22796109]

Rabinak CA, Phan KL. Cannabinoid modulation of fear extinction brain circuits a novel target to advance anxiety treatment. Current Pharmaceutical Design. 2014; 20(13):2212-2217. [PubMed: 23829364]

Ratano P, Everitt BJ, Milton AL. The CB1 receptor antagonist am251 impairs reconsolidation of pavlovian fear memory in the rat basolateral amygdala. Neuropsychopharmacology. 2014; 39(11):2529-2537. http://dx.doi.org/10.1038/npp.2014.103. [PubMed: 24801769]

Rauch SL, Shin LM, Phelps EA. Neurocircuitry models of posttraumatic stress disorder and extinction: Human neuroimaging research—past, present, and future. Biological Psychiatry. 2006; 60(4): 376-382. [PubMed: 16919525]

Reich CG, Mohammadi MH, Alger BE. Endocannabinoid modulation of fear responses: Learning and state-dependent performance effects. Journal of Psychopharmacology. 2008; 22(7):769-777. [PubMed: 18308796]

Reich CG, Taylor ME, McCarthy MM. Differential effects of chronic unpredictable stress on hippocampal CB1 receptors in male and female rats. Behavioural Brain Research. 2009; 203(2): 264-269. [PubMed: 19460405]

Rescorla RA. Spontaneous recovery. Learning and Memory. 2004; 11(5):501-509. http://dx.doi.org/ 10.1101/lm.77504. [PubMed: 15466300]

Roitman P, Mechoulam R, Cooper-Kazaz R, Shalev A. Preliminary, open-label, pilot study of add-on oral $\Delta$-tetrahydrocannabinol in chronic post-traumatic stress disorder. Clinical Drug Investigation. 2014; 34(8):587-591. [PubMed: 24935052]

Rothbaum BO, Davis M. Applying learning principles to the treatment of post-trauma reactions. Annals of the New York Academy of Sciences. 2003; 1008(1):112-121. [PubMed: 14998877]

Rougemont-Bücking A, Linnman C, Zeffiro TA, Zeidan MA, Lebron-Milad K, Rodriguez-Romaguera $\mathrm{J}$, et al. Altered processing of contextual information during fear extinction in PTSD: An fMRI study. CNS Neuroscience \& Therapeutics. 2011; 17(4):227-236. [PubMed: 20406268]

Rucker D, Padwal R, Li SK, Curioni C, Lau DC. Long term pharmacotherapy for obesity and overweight: Updated meta-analysis. BMJ. 2007; 335(7631):1194-1199. [PubMed: 18006966] 
Ruehle S, Rey AA, Remmers F, Lutz B. The endocannabinoid system in anxiety, fear memory and habituation. Journal of Psychopharmacology. 2012; 26(1):23-39. http://dx.doi.org/ 10.1177/0269881111408958. [PubMed: 21768162]

Ruglass LM, Lopez-Castro T, Cheref S, Papini S, Hien DA. At the crossroads: The intersection of substance use disorders, anxiety disorders, and posttraumatic stress disorder. Current Psychiatry Reports. 2014; 16(11):1-9.

Schafe GE, Nadel NV, Sullivan GM, Harris A, LeDoux JE. Memory consolidation for contextual and auditory fear conditioning is dependent on protein synthesis, pka, and map kinase. Learning and Memory. 1999; 6(2):97-110. [PubMed: 10327235]

Segev A, Akirav I. Differential effects of cannabinoid receptor agonist on social discrimination and contextual fear in amygdala and hippocampus. Learning and Memory. 2011; 18(4):254-259. [PubMed: 21447623]

Semple DM, McIntosh AM, Lawrie SM. Cannabis as a risk factor for psychosis: Systematic review. Journal of Psychopharmacology. 2005; 19(2):187-194. [PubMed: 15871146]

Shin LM, Liberzon I. The neurocircuitry of fear, stress, and anxiety disorders. Neuropsychopharmacology. 2010; 35(1):169-191. [PubMed: 19625997]

Shvil E, Sullivan GM, Schafer S, Markowitz JC, Campeas M, Wager TD, et al. Sex differences in extinction recall in posttraumatic stress disorder: A pilot fmri study. Neurobiology of Learning and Memory. 2014; 113:101-108. http://dx.doi.org/10.1016/j.nlm.2014.02.003. [PubMed: 24560771]

Siegmund A, Wotjak CT. Toward an animal model of posttraumatic stress disorder. Annals of the New York Academy of Sciences. 2006; 1071(1):324-334. [PubMed: 16891581]

Sripada RK, Garfinkel SN, Liberzon I. Avoidant symptoms in PTSD predict fear circuit activation during multimodal fear extinction. Frontiers in Human Neuroscience. 2013; 7:672. [PubMed: 24146643]

Sullivan, GM.; Debiec, J.; Bush, DEA.; Lyons, DM.; Ledoux, JE. The neurobiology of fear and anxiety: Contributions of animal models to current understanding. In: Charney, DS.; Nestler, EJ., editors. Neurobiology of mental illness. 3. New York: Oxford; 2009. p. 603-626.

Suzuki A, Josselyn SA, Frankland PW, Masushige S, Silva AJ, Kida S. Memory reconsolidation and extinction have distinct temporal and biochemical signatures. Journal of Neuroscience. 2004; 24(20):4787-4795. http://dx.doi.org/10.1523/JNEUROSCI.5491-03.2004. [PubMed: 15152039]

Terzian AL, Drago F, Wotjak CT, Micale V. The dopamine and cannabinoid interaction in the modulation of emotions and cognition: Assessing the role of cannabinoid CB1 receptor in neurons expressing dopamine d1 receptors. Frontiers in Behavioral Neuroscience. 2011; 5:49. [PubMed: 21887137]

Tronson NC, Taylor JR. Molecular mechanisms of memory reconsolidation. Nature Reviews Neuroscience. 2007; 8(4):262-275.

Van Emmerik AAP, Kamphuis JH, Hulsbosch AM, Emmelkamp PMG. Single session debriefing after psychological trauma: A meta-analysis. Lancet. 2002; 360(9335):766-771. [PubMed: 12241834]

Vervliet B, Craske MG, Hermans D. Fear extinction and relapse: State of the art. Annual Review of Clinical Psychology. 2013; 9:215-248. http://dx.doi.org/10.1146/annurevclinpsy-050212-185542.

Vianna MR, Coitinho AS, Izquierdo I. Role of the hippocampus and amygdala in the extinction of fear-motivated learning. Current Neurovascular Research. 2004; 1:55-60. [PubMed: 16181066]

Yamada D, Takeo J, Koppensteiner P, Wada K, Sekiguchi M. Modulation of fear memory by dietary polyunsaturated fatty acids via cannabinoid receptors. Neuropsychopharmacology. 2014; 39:1852-1860. [PubMed: 24518289]

Yehuda R, Antelman SM. Criteria for rationally evaluating animal models of postraumatic stress disorder. Biological Psychiatry. 1993; 33(7):479-486. [PubMed: 8513032]

Zarrindast MR, Babapoor-Farrokhran S, Babapoor-Farrokhran S, Rezayof A. Involvement of opioidergic system of the ventral hippocampus, the nucleus accumbens or the central amygdala in anxiety-related behavior. Life Sciences. 2008; 82(23):1175-1181. [PubMed: 18456284] 


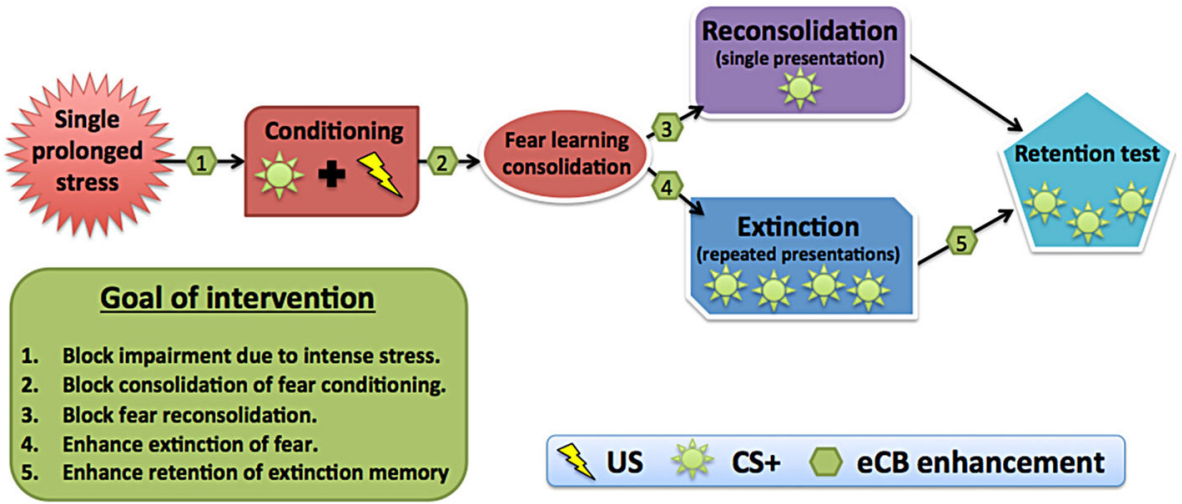

Fig. 1.

Targeting the eCB system in experimental paradigms of fear processing. US = unconditioned stimulus (e.g., shock); $\mathrm{CS}+=$ conditioned stimulus (e.g., colored light); eCB $=$ endocannabinoid. Enhancement includes use of direct and indirect CB1 receptor agonists. 


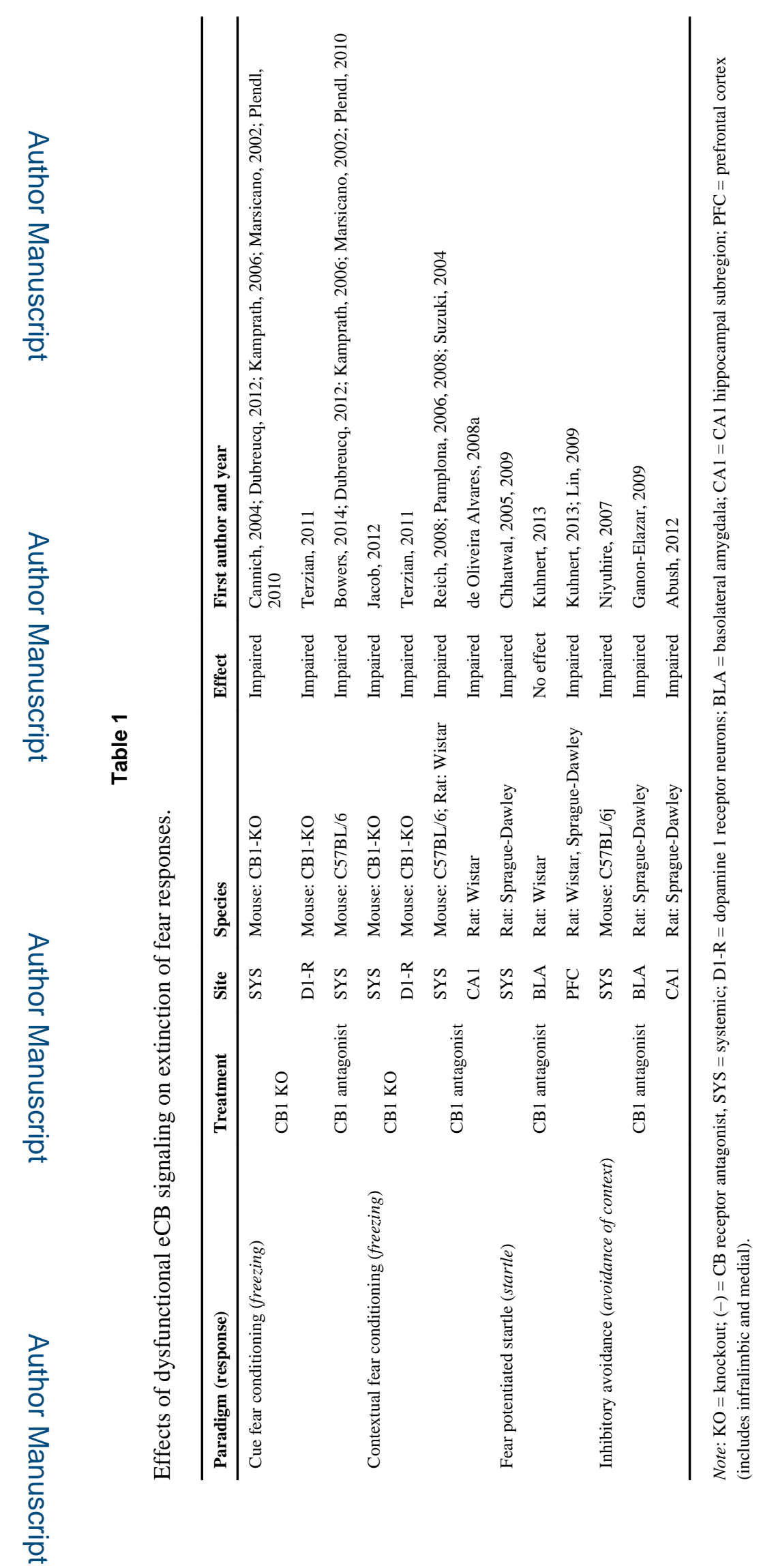

Biol Psychol. Author manuscript; available in PMC 2016 January 01. 


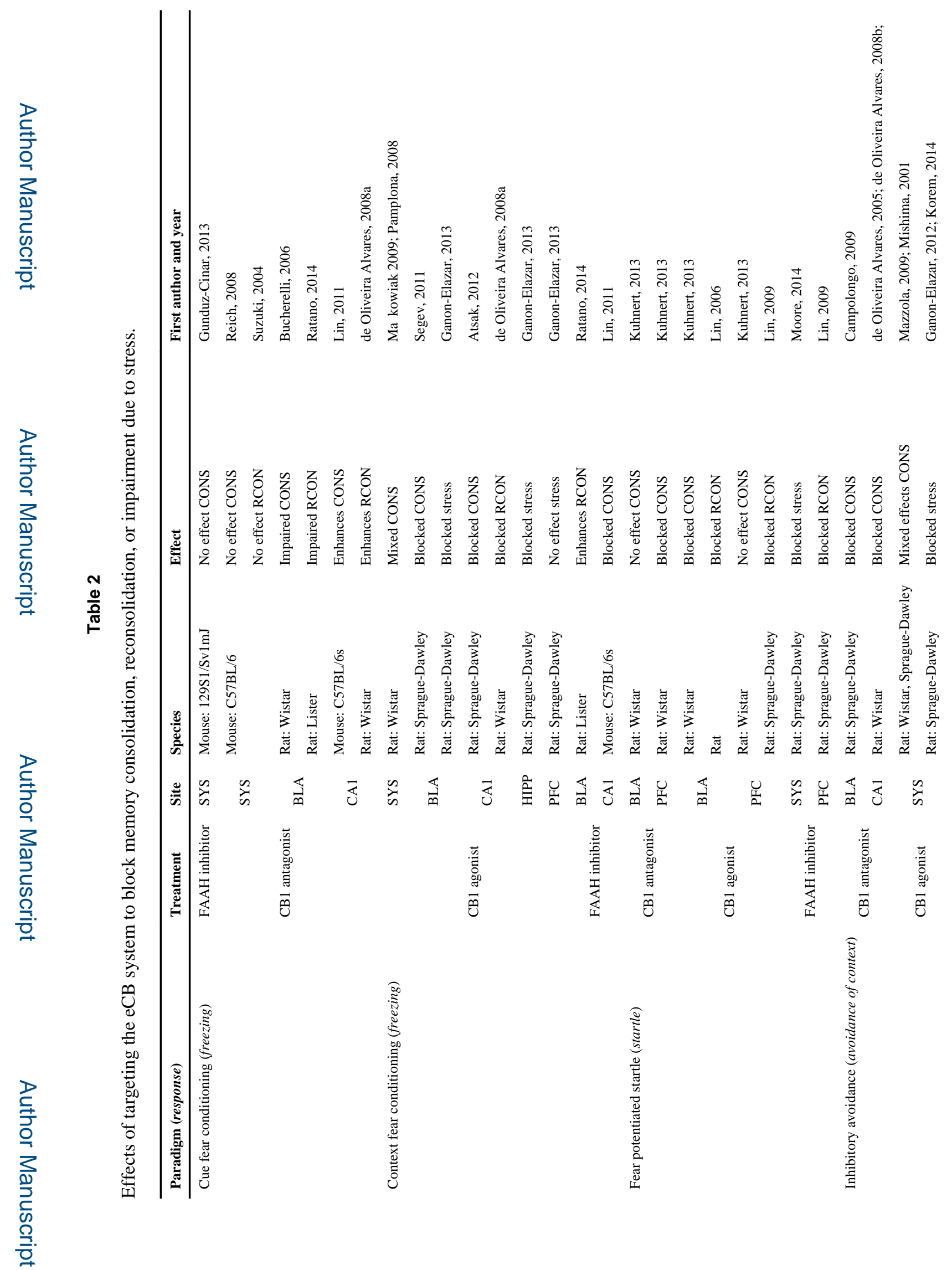

Biol Psychol. Author manuscript; available in PMC 2016 January 01. 
Papini et al.

Page 25

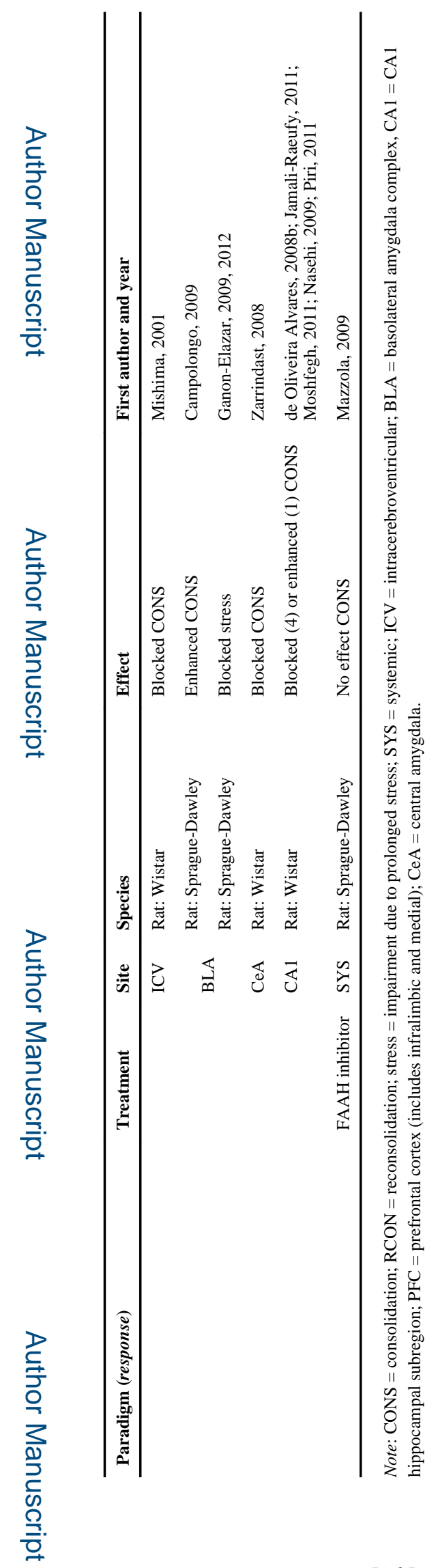

Biol Psychol. Author manuscript; available in PMC 2016 January 01. 


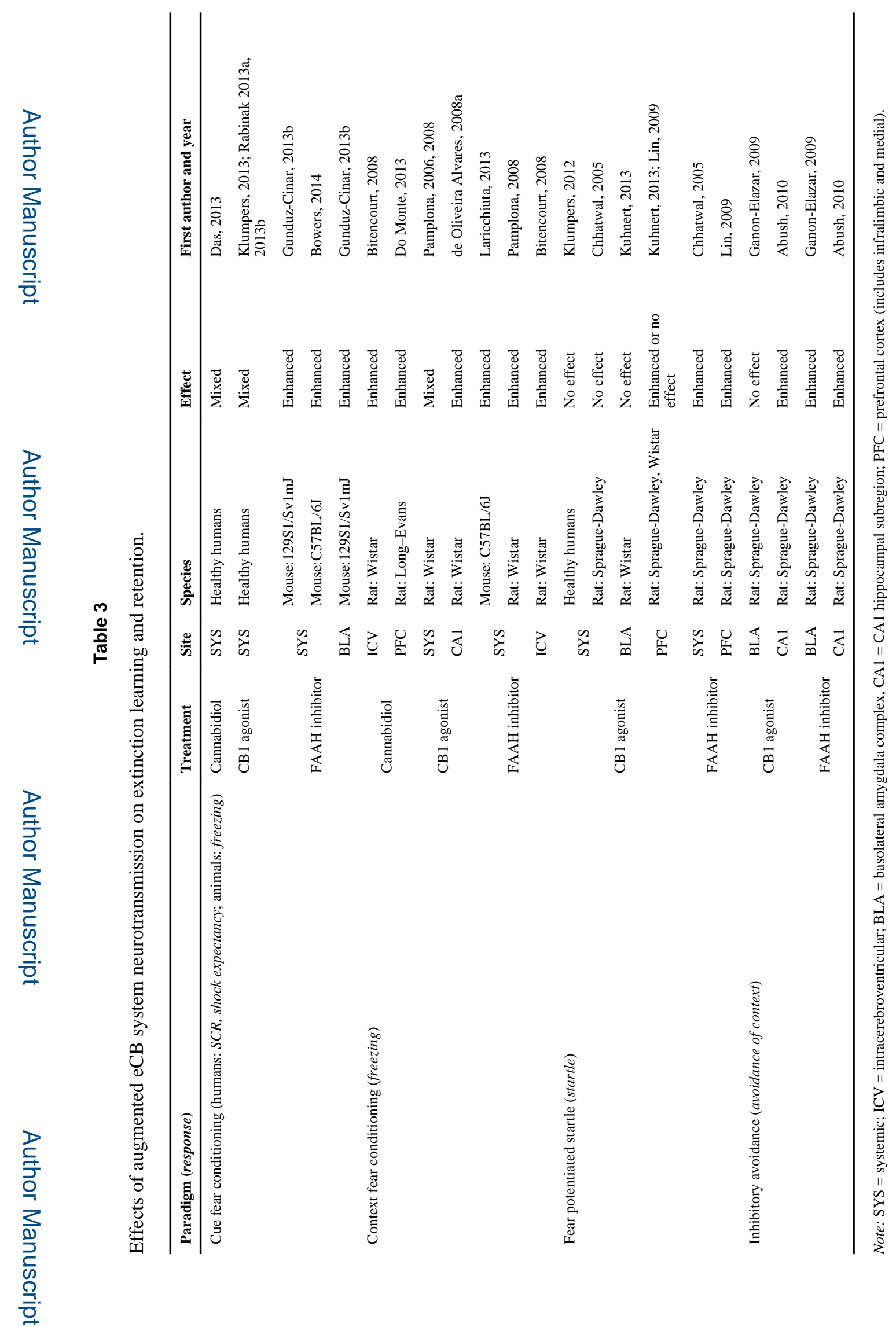

Biol Psychol. Author manuscript; available in PMC 2016 January 01. 